\title{
Temperature-sensitive Mutants of the Streptomyces Plasmid pIJ702
}

\author{
By ASHLEY W. BIRCH AND JOHN CULLUM* \\ Department of Biochemistry and Applied Molecular Biology, University of Manchester Institute \\ of Science and Technology, PO Box 88, Sackville Street, Manchester M60 1QD, UK
}

(Received 22 November 1984; revised 21 January 1985)

DNA from the Streptomyces plasmid pIJ702 was mutagenized in vitro using hydroxylamine and transformed into Streptomyces lividans. One plasmid with temperature-sensitive replication (pMT660) and one plasmid with a temperature-sensitive tyrosinase (pMT661) were isolated. The plasmid pMT661 contains a novel PstI restriction endonuclease site within the tyrosinase gene.

\section{INTRODUCTION}

Temperature-sensitive plasmid replication mutants should be very useful in the study of Streptomyces. Such mutants could be used to force replicon fusions and possibly reveal the presence of transposable elements, as has been demonstrated in Escherichia coli (Ohtsubo et al., 1980). In addition, they could be used as convenient vectors for the development of a transposon mutagenesis system, the advantages of which have already been well defined in other species (Kleckner et al., 1977). There are also other experiments where easy elimination of plasmid encoded sequences from a cell is desired.

We used the chemical mutagen, hydroxylamine (Humphreys et al., 1978), to produce a temperature-sensitive mutation of plasmid pIJ702 (Katz et al., 1983), which is a widely used cloning vector. The mutagenesis was done in vitro on plasmid DNA, the DNA being subsequently introduced into Streptomyces lividans by transformation for recovery of mutants. Such a mutagenesis procedure permits high level mutagenesis of a small genome, coupled with easy control of the level of the mutagenic treatment. The plasmid pIJ702 was used because it can be introduced into most Streptomyces species; it is a derivative of the broad host range plasmid pIJ101 (Kieser et al., 1982). It carries the easily identified genes for thiostrepton resistance and melanin production, thus allowing easy assay of mutagenesis.

We report here the successful generation of a temperature-sensitive plasmid replication mutant and a temperature-sensitive tyrosinase mutant.

\section{METHODS}

Bacterial strains and culture conditions. S. lividans strain TK64 (pro-2, str-6, SLP2-, SLP3-) (Hopwood et al., 1983) and $S$. lividans strain 3131 containing the plasmid vector pIJ702 (Katz et al., 1983) were kindly supplied by Professor D. A. Hopwood (John Innes Institute, Norwich, UK). They were cultured on the following media: CM (complete medium; Hopwood, 1967), nutrient agar (Oxoid) and R2YE (regeneration yeast extract medium; Chater et al., 1982). The melanin (Mel) phenotype of plasmid pIJ702 was scored by the addition of tyrosine $\left(400 \mu \mathrm{g} \mathrm{ml}^{-1}\right)$, methionine $\left(100 \mu \mathrm{g} \mathrm{ml}^{-1}\right)$ and $\mathrm{CuSO}_{4} \cdot 5 \mathrm{H}_{2} \mathrm{O}\left(5 \mu \mathrm{g} \mathrm{ml}^{-1}\right)(\mathrm{Kieser}, 1979)$. All liquid cultures were grown in LB (Luria broth; Maniatis et al., 1982) except for the tyrosinase assay for which glucose/yeast extract medium (Lerch \& Ettlinger, 1972) was used. Thiostrepton (E. J. Squibb and Sons, New Brunswick, NJ, USA) was added to liquid media $\left(5 \mu \mathrm{g} \mathrm{ml}^{-1}\right)$ and solid media $\left(50 \mu \mathrm{g} \mathrm{m}^{-1}\right)$. Transformants were selected by overlaying the $\mathrm{R} 2 \mathrm{YE}$ regeneration plates with liquid tryptone/salt medium $\left(0.6 \%(\mathrm{w} / \mathrm{v})\right.$ agar, $16 \mathrm{~g}$ tryptone $1^{-1}, 10 \mathrm{~g}$ yeast extract $\left.1^{-1}, 5 \mathrm{~g} \mathrm{NaCl}^{-1}\right)$ containing thiostrepton $\left(500 \mu \mathrm{g} \mathrm{ml}^{-1}\right), 16 \mathrm{~h}$ after transformation. Normal $\left(28^{\circ} \mathrm{C}\right)$ and restrictive $\left(39^{\circ} \mathrm{C}\right)$ incubation temperatures were used. 
Isolation of genomic DNA. Cells were grown for 4 to $5 \mathrm{~d}$ in LB $(100 \mathrm{ml})$, harvested and washed in $10 \cdot 3 \%(\mathrm{w} / \mathrm{v})$ sucrose. After resuspension in $5 \mathrm{ml}$ lysozyme solution $(10 \cdot 3 \%(\mathrm{w} / \mathrm{v})$ sucrose, $25 \mathrm{~mm}$-EDTA, $25 \mathrm{~mm}$-Tris $\mathrm{pH} 8.0$, $2 \mathrm{mg}$ lysozyme $\left.\mathrm{ml}^{-1}\right)$ the cells were incubated for $1 \mathrm{~h}$ at $37^{\circ} \mathrm{C}$, and then $0.7 \mathrm{ml}$ protease $\left(10 \mathrm{mg} \mathrm{ml}^{-1}\right.$; Papaya, Sigma) and $1.2 \mathrm{ml} 0.5 \mathrm{M}$-EDTA were added. After incubation for $10 \mathrm{~min}$ at $37^{\circ} \mathrm{C}$ the cells were lysed by the addition of $1 \mathrm{ml} 10 \%(\mathrm{w} / \mathrm{v})$ SDS and were incubated for $1 \mathrm{~h}$. Sodium chloride was added to a concentration of $0.5 \mathrm{M}$ and protein extracted using $5 \mathrm{ml}$ phenol equilibrated with $\mathrm{TE} / 0.5 \mathrm{M}-\mathrm{NaCl} / 0 \cdot 01 \%(\mathrm{w} / \mathrm{v})$ hydroxyquinoline (TE, $10 \mathrm{~mm}$-Tris/1 mM-EDTA pH 8.0). After centrifugation $(20 \mathrm{~min}, 16000$ r.p.m., $23600 \mathrm{~g}$ ) in a Sorvall SS34 rotor, DNA was precipitated from the aqueous phase by the addition of isopropanol. The DNA was recovered by centrifugation ( $10 \mathrm{~min}, 10000$ r.p.m., $9200 \mathrm{~g}$ ), resuspended in TE containing $40 \mu \mathrm{g}$ RNAase ml ${ }^{-1}$ and incubated for $30 \mathrm{~min}$ at $37^{\circ} \mathrm{C}$. The DNA was then subjected to a second phenol extraction and isopropanol precipitation, and was resuspended in $5 \mathrm{ml} \mathrm{TE}$ buffer. It was subjected to a further isopropanol precipitation in order to remove all traces of phenol.

Isolation of plasmid DNA. Plasmid DNA was isolated according to the method of Kieser (1984) for small scale work. Large scale preparations were made as follows: cultures in LB $(100 \mathrm{ml})$ containing thiostrepton $\left(5 \mu \mathrm{g} \mathrm{ml} \mathrm{m}^{-1}\right)$ were harvested after 3 to $4 \mathrm{~d}$ and resuspended in $10 \mathrm{ml}$ buffer $(10 \cdot 3 \%(\mathrm{w} / \mathrm{v})$ sucrose, $25 \mathrm{~mm}$-EDTA, $25 \mathrm{~mm}$-Tris $)$. The cells were incubated for $30 \mathrm{~min}$ at $37^{\circ} \mathrm{C}$ after the addition of $1 \mathrm{ml}$ lysozyme solution $(50 \mathrm{~mm}-\mathrm{Tris} / \mathrm{HCl} \mathrm{pH} 8.0$ containing $40 \mathrm{mg}$ lysozyme $\mathrm{ml}^{-1}$ ). Lysis was achieved by adding $20 \mathrm{ml} 0 \cdot 2 \mathrm{M}-\mathrm{NaOH} / 1 \%(\mathrm{w} / \mathrm{v}) \mathrm{SDS}$. After $5 \mathrm{~min}$ on ice, protein, high molecular weight RNA and chromosomal DNA were precipitated by the addition of $15 \mathrm{ml} 3 \mathrm{M}$ sodium acetate $\mathrm{pH} 4.8$ and were left on ice for $1 \mathrm{~h}$. The precipitate was pelleted by centrifugation ( $30 \mathrm{~min}$, 12000 r.p.m., $19200 \mathrm{~g}$ ). Plasmid DNA was precipitated from the aqueous phase by the addition of ethanol $(120 \mathrm{ml})$ and was left at $-20^{\circ} \mathrm{C}$ for $1 \mathrm{~h}$. After centrifugation the pellet was resuspended in $\mathrm{TE}$ buffer $(10 \mathrm{ml})$, to which was added caesium chloride $(10.25 \mathrm{~g})$ and $0.25 \mathrm{ml}$ ethidium bromide $\left(10 \mathrm{mg} \mathrm{ml}^{-1}\right)$. This was centrifuged $(60 \mathrm{~h}, 36000$ r.p.m., $90000 \mathrm{~g})$ in a Ti50 rotor in an L5-50B ultracentrifuge (Beckman). DNA bands were visualized using UV light.

Hydroxylamine mutagenesis. Samples of pure plasmid DNA were added to TE buffer to give a final concentration of $2 \mu \mathrm{g}$ in $60 \mu \mathrm{l}$. To this was added $180 \mu \mathrm{l}$ hydroxylamine solution (hydroxylamine $\mathrm{HCl} 1 \cdot 5 \mathrm{M}$, EDTA $25 \mathrm{~mm} \mathrm{pH} \mathrm{6.0),} 5 \mu \mathrm{l} 0.25 \mathrm{M}$-EDTA and $13 \mu \mathrm{l} 1 \mathrm{M}$-Tris $/ \mathrm{HCl} \mathrm{pH} \mathrm{8.0.} \mathrm{The} \mathrm{reaction} \mathrm{mixture} \mathrm{was} \mathrm{then} \mathrm{incubated} \mathrm{for}$ $30 \mathrm{~min}$ at the required temperature without agitation. DNA was precipitated by the addition of sodium acetate ( $\mathrm{pH} 6.0$ ), to a concentration of $0.4 \mathrm{M}$, and $800 \mu \mathrm{l}$ absolute ethanol, and $15 \mathrm{~min}$ incubation at $-70^{\circ} \mathrm{C}$. The DNA was recovered by centrifugation and resuspended in $20 \mu \mathrm{l} \mathrm{TE}$ and $20 \mu \mathrm{l} 10 \cdot 3 \%(\mathrm{w} / \mathrm{v})$ sucrose for transformation into $S$. lividans. Protoplasts were prepared by the method of Chater et al. (1982). Transformants were selected as described above.

Restriction endonuclease mapping of plasmids. All restriction enzymes were bought from Boehringer. DNA fragments were separated using horizontal agarose gel electrophoresis in TBE (Tris/borate/EDTA buffer) and agarose concentrations between $0.7 \%(\mathrm{w} / \mathrm{v})$ and $1.5 \%(\mathrm{w} / \mathrm{v})$ (Maniatis et al., 1982). Size markers were constructed by digesting phage $\lambda$ DNA with each of the following restriction endonucleases: EcoRI, HindIII, BglI. The fragment sizes were calculated from the published $\lambda$ DNA sequence (Sanger et al., 1982).

Determination of enzyme activity. Crude extracts containing the tyrosinase enzyme (EC 1.14.18.1) were prepared from liquid culture using essentially the method described by Katz et al. (1983). Induction of the tyrosinase was achieved by the addition of methionine $\left(10 \mu \mathrm{g} \mathrm{ml}^{-1}\right)$ (Baumann \& Kocher, 1976) and $\mathrm{CuSO}_{4} .5 \mathrm{H}_{2} \mathrm{O}\left(5 \mu \mathrm{g} \mathrm{ml}^{-1}\right)$.

The temperature sensitivity of the tyrosinases isolated by this method was assayed by subjecting samples of the enzyme extracts to incubation for $15 \mathrm{~min}$ at various temperatures before measuring their activity at $30^{\circ} \mathrm{C}$. Tyrosinase activity was determined using the dopachrome assay procedure of Lerch \& Ettlinger (1972) with LDOPA (dihydroxyphenylalanine) as substrate and using the conditions of Katz et al. (1983). Formation of the pigment dopachrome was followed by measuring the increase in absorbance at $475 \mathrm{~nm}$ using a Cecil CE292 digital spectrophotometer (Cambridge, England).

The protein concentrations of the crude extracts were assayed using the Bio-Rad protein assay kit.

\section{RESULTS AND DISCUSSION}

\section{Mutagenesis of plasmid pIJ702}

Plasmid pIJ702 contains two markers, the thiostrepton resistance gene ( $t s r)$ and the tyrosinase gene (mel). The former gene was used to select for transformants; the latter, whose expression leads to the production of black melanin pigment, was used to assay the efficiency of the hydroxylamine mutagenesis.

Hydroxylamine mutagenesis was known to be strongly temperature dependent (Humphreys et al., 1978), and this is probably because transient DNA strand separation is necessary. Preliminary experiments indicated that an incubation temperature in the range of $75^{\circ} \mathrm{C}$ to $85^{\circ} \mathrm{C}$ 
was capable of producing an acceptable level of both mutagenesis and plasmid survival. The degree of mutagenesis was monitored by scoring the appearance of $\mathrm{Mel}^{-}$colonies. At an incubation temperature of $81^{\circ} \mathrm{C}$, plasmid survival was 1 to $5 \%$ and $1 \%$ of the thiostrepton resistant colonies were $\mathrm{Mel}^{-}$. The background of spontaneously $\mathrm{Mel}^{-}$mutants of $\mathrm{pIJ} 702$ was $0.1 \%$, but all spontaneous $\mathrm{Mel}^{-}$mutants had easily detectable deletions (seven of seven tested). DNA from $15 \mathrm{Mel}^{-}$thistrepton resistant colonies, found after hydroxylamine mutagenesis, were screened by agarose gel electrophoresis. Only two showed evidence of deletions, the remaining 13 were the same size as pIJ 702 and thus probably carried hydroxylamine-induced base changes.

\section{Selection strategy}

Hydroxylamine mutagenized pIJ702 DNA was transformed into $S$. lividans TK64 protoplasts and transformants were selected at $28^{\circ} \mathrm{C}$. After sporulation, the transformants were patched to pairs of $\mathrm{CM}$ plates which were incubated at $28^{\circ} \mathrm{C}$ and $39^{\circ} \mathrm{C}$. The highest temperature which permitted sufficient sporulation for subsequent replica platings was $39^{\circ} \mathrm{C}$. After sporulation, the master plates from each temperature were replica plated to nutrient agar plates containing thiostrepton, and control plates lacking the antibiotic. The replica plates were incubated at the same temperature as their respective master plates. The plates were then scored for possible temperature-sensitive plasmid replication mutants. Such candidates exhibited a simultaneous loss of thiostrepton resistance and ability to produce the black pigment melanin at $39^{\circ} \mathrm{C}$. A total of 800 colonies were screened and eight candidates were isolated. After retesting, these proved to include a temperature-sensitive replication mutant (pMT660) and a temperature-sensitive tyrosinase mutant (pMT661); the other six candidates were indistinguishable from pIJ702.

We have demonstrated the suitability of hydroxylamine treatment in vitro for generating plasmid mutants of Streptomyces. A high incubation temperature of $81{ }^{\circ} \mathrm{C}$ (compared to $60^{\circ} \mathrm{C}$ for an E. coli plasmid; Humphreys et al., 1978) is necessary probably because of the high $\mathrm{G}+\mathrm{C}$ content of Streptomyces DNA. This mutagenesis system gives reproducible results and high yields of mutants with low lethality. Thus, hydroxylamine is an attractive mutagen for use with Streptomyces plasmids.

\section{A temperature-sensitive plasmid replication mutant, pMT660, of pIJ702}

$S$. lividans TK64 containing plasmid pMT660 exhibited a simultaneous loss of thiostrepton resistance and melanin production at $39^{\circ} \mathrm{C}$. Plasmid DNA was isolated from the strain after growth at $28^{\circ} \mathrm{C}$. The temperature-sensitive phenotype was retained on retransformation, locating the lesion to the plasmid. Growth at $39^{\circ} \mathrm{C}$ on R2YE for $6 \mathrm{~d}$ (R2YE inoculated with $200 \mu \mathrm{l}$ of a $5 \mathrm{ml}$ spore suspension prepared from a confluent sporulating R2YE + thiostrepton plate at $28^{\circ} \mathrm{C}$ ) followed by subsequent incubation at $28^{\circ} \mathrm{C}$ failed to recover the plasmid determined phenotypes, indicating that the plasmid is lost on incubation at $39^{\circ} \mathrm{C}$. Repeated attempts to isolate plasmid DNA after growth at $39^{\circ} \mathrm{C}$ proved unsuccessful. Total DNA was prepared from the strain after growth at $39^{\circ} \mathrm{C}$; it was digested with the enzyme $B c l$ I and subjected to horizontal agarose gel electrophoresis. The DNA was transferred to a Biodyne filter (Pall Ultrafine Filtration Corp., Glen Cove, NY 11542, USA) by the procedure of Southern (1975) and hybridized to ${ }^{32}$ P-labelled (Rigby et al., 1977) pIJ702 DNA. No hybridization, in conditions which would reveal even single copy sequences, was seen, demonstrating that growth at $39^{\circ} \mathrm{C}$ resulted in the total loss of plasmid DNA sequences from the cell.

The plasmid pMT660 was indistinguishable from pIJ702 when digested with the following enzymes: BamHI, BclI, BglII, Eco RI, HindIII, KpnI, PstI, SacI,SacII,Sal GI,SmaI, XhoI, XhoII. pMT660 should prove to be a valuable tool for use in the detection of transposable elements in replicon fusions of Streptomyces DNA, and it could be employed as a vehicle in a transposon mutagenesis system. Additionally, pMT660 might be used as an alternative to phage $\phi \mathrm{C} 31$ based vectors used in mutational cloning systems (Chater \& Bruton, 1983). We have already used this plasmid to isolate fusions in which the vector has integrated into the host's chromosomal sequences under selection at $39^{\circ} \mathrm{C}$ (unpublished results). Investigation of the junction sequences of these fusions is now under way. 


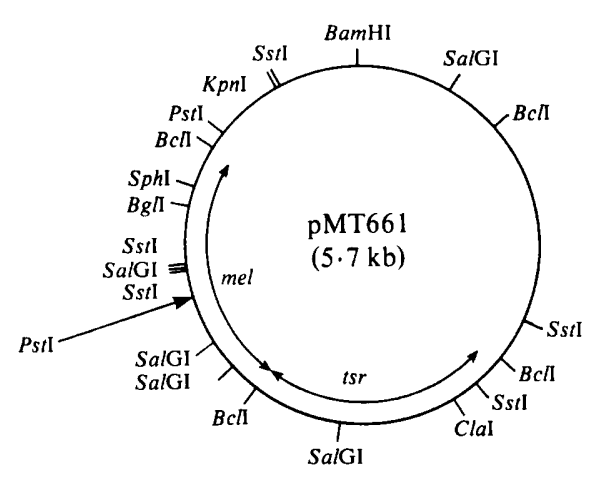

Fig. 1. Restriction map of pMT661, a temperature-sensitive tyrosinase mutant of pIJ702.

\section{A temperature-sensitive tyrosinase mutant, pMT661, of pIJ702}

$S$. lividans TK 64 containing plasmid pMT661 was thiostrepton resistant, but failed to produce melanin at $39^{\circ} \mathrm{C}$. The ability to produce this pigment was, however, recovered at $28^{\circ} \mathrm{C}$. Plasmid DNA was prepared from the strain grown at $28^{\circ} \mathrm{C}$ and $39^{\circ} \mathrm{C}$. The temperature-sensitive phenotype was retained on retransformation, indicating a plasmid location for the lesion. We assayed the temperature-sensitivity of the tyrosinase enzyme by preparing crude enzyme extracts (see Methods) from strains carrying pIJ702, pMT660 and pMT661. The enzyme activity was assayed at $30^{\circ} \mathrm{C}$. Samples of the enzyme were subjected to a 15 min pre-incubation at different temperatures in order to determine the heat-lability of the tyrosinase. Activities were corrected for protein concentrations in the extract and compared to a standard activity (tyrosinase from pIJ702 at $30^{\circ} \mathrm{C}$ ). These results showed only a slight drop in activity of the enzymes from strains containing pIJ702 and pMT660 over a temperature range of $30{ }^{\circ} \mathrm{C}$ to $50{ }^{\circ} \mathrm{C}$. The tyrosinase from pMT661, however had the following activities over this temperature range: $30{ }^{\circ} \mathrm{C}, 40 \% ; 39{ }^{\circ} \mathrm{C}, 10 \% ; 45^{\circ} \mathrm{C},<0.5 \% ; 50{ }^{\circ} \mathrm{C}$, no detectable activity. This shows that the pMT661-encoded tyrosinase has a marked heat-lability, suggesting that the mutation is indeed in the tyrosinase coding sequence.

Plasmid pMT661 was subjected to a restriction analysis using the enzymes described previously. The vector contained a novel Pst I site. This new site was mapped to a point with the co-ordinates $3.85 \mathrm{~kb}$ in the pIJ702 map of Katz et al. (1983) (Fig. 1) and is within the tyrosinase coding region (M. Bibb, personal communication). The novel PstI site is probably the site of the temperature-sensitive lesion. Only $1 \%$ of mutagenized survivors showed a $\mathrm{Mel}^{-}$phenotype; hence, the probability of two independent mutagenic events occurring within the melanin gene is small.

The recovery of this mutant was fortuitous because the initial screening was for loss of thiostrepton resistance. The mutant was probably isolated by mistake due to poor replication to the thiostrepton-containing plates. At present, work is under way to eliminate the original PstI site, at $4.85 \mathrm{~kb}$, from pMT661 in order to construct a cloning vector in which the tyrosinase gene is inactivated by insertion into a single Pst I site.

We thank the SERC for a project grant to J.C. We thank Kevin Kendall and Josef Altenbuchner for useful discussions, Jacqueline Platt for technical assistance and Mr S. J. Lucania of E. J. Squibb and Sons, New Brunswick, NJ, USA, for the gift of thiostrepton.

\section{REFERENCES}

Baumann, R. \& Kocher, H. P. (1976). Genetics of Streptomyces glaucescens and regulation of melanin production. In Second International Symposium on the
Genetics of the Industrial Microorganisms, pp. 535551. Edited by K. D. MacDonald, London: Academic Press. 
Chater, K. F. \& Bruton, C. J. (1983). Mutational cloning in Streptomyces and the isolation of antibiotic production genes. Gene 26, 67-78.

Chater, K. F., Hopwood, D. A., Kieser, T. \& Thompson, C. J. (1982). Gene cloning in Streptomyces. Current Topics in Microbiology and Immunology 97, 69-95.

HoPwOOD, D. A. (1967). Genetic analysis and genome structure in Streptomyces coelicolor. Bacteriological Reviews 31, 373-403.

Hopwood, D. A., Kieser, T., Wright, H. M. \& BibB, M. J. (1983). Plasmids, recombination and chromosome mapping in Streptomyces lividans. Journal of General Microbiology 129, 42-48.

Humphreys, G. O., Willshaw, G. A., Smith, H. R. \& ANDERSON, E. S. (1978). Mutagenesis of plasmid DNA with hydroxylamine:isolation of mutants of multicopy plasmids. Molecular and General Genetics 145, 101-108.

KatZ, E., Thompson, C. J. \& Hopwood, D. A. (1983). Cloning and expression of the tyrosinase gene from Streptomyces antibioticus in Streptomyces lividans. Journal of General Microbiology 129, 2703-2714.

KIESER, T. (1979). Untersuchung von genetisch instabilen Eigenschaften von Streptomyces glaucescens. PhD. thesis no. 6473, Eidgenössische Technische Hochschule, Zürich, Switzerland.

KIESER, T. (1984). Factors affecting the isolation of ccc DNA from Streptomyces lividans and Escherichia coli. Plasmid 12, 19-36.

KIESER, T., HoPWOOD, D. A., Wright, H. M. \&
Thompson, C. J. (1982). pIJ101, a multicopy broad host-range Streptomyces plasmid: functional analysis and development of DNA cloning vectors. Molecular and General Genetics 185, 223-238.

KLECKNER, N., Roth, J. \& BotsteIN, D. (1977). Genetic engineering in vitro using translocatable drug-resistance elements. Journal of Molecular Bio$\log y$ 116, 125-159.

Lerch, K. \& Ettlinger, L. (1972). Purification and characterization of a tyrosinase from Streptomyces glaucescens. European Journal of Biochemistry 31, 427-437.

Maniatis, T., Fritsch, E. F. \& SAmbrooK, J. (1982). Molecular Cloning, a Laboratory Manual. Cold Spring Harbor, NY: Cold Spring Harbor Laboratory.

Ohtsubo, H., Zenilman, M. \& Ohtsubo, E. (1980). Insertion element IS102 resides in plasmid pSC101. Journal of Bacteriology 144, 131-140.

Rigby, P. W. J., Dieckmann, M., Rhodes, C. \& Berg, P. (1977). Labelling deoxyribonucleic acid to high specific activity in vitro by nick-translation with DNA polymerase 1. Journal of Molecular Biology 113, 237-251.

Sanger, F., Coulson, A. R., Hong, G. F., Hill, D. F. \& Peterson, G. B. (1982). Nucleotide sequence of bacteriophage lambda DNA. Journal of Molecular Biology 162, 729-773.

SouTHERN, E. M. (1975). Detection of specific sequences among DNA fragments separated by gel electrophoresis. Journal of Molecular Biology 98, 503-517. 